\title{
Introduction: New Perspectives on Irish Folklore
}

\author{
Audrey Robitaillié and Marjan Shokouhi
}

Copyright (c) 2017 by Audrey Robitaillié and Marjan Shokouhi. This text may be archived and redistributed both in electronic form and in hard copy, provided that the author and journal are properly cited and no fee is charged for access.

According to folk beliefs, people say that the fairies are out on the night of Samhain: "Deireann na daoine go mbíonn sidheogaí amuigh oidhche Shamhna", in the words of an informant for the Schools' Collection (NFCS 249). And so is this special issue of Estudios Irlandeses entitled "New Perspectives on Irish Folklore"! Far less risky than venturing out on the festival night, but equally audacious, this volume explores the rich traditions of Irish folklore and the various ways it is being/has been reused, repurposed and reinvented. The contributions to this issue explore multiple aspects of folklore today: from the tribulations of the folklore collectors to the reimagining of folklore for the stage, and its reuse in literature and musical compositions.

Marina Warner asserts that "Every telling of a myth is a part of that myth: there is no Ur-version, no authentic prototype, no true account" (8). The same could be said of folklore, which is intertwined with mythology on many levels, for that matter. There are multiple variants of a tale type, many interpretations of a folk tune, and numerous versions of a rhyme, which all depend on the circumstances of the transmission, the informant, their locations, and so on. Folklore is a living, multi-faceted process that has as many shapes and forms as there are individuals who engage with it. It has therefore proved quite challenging to define. The Irish word for it, béaloideas, which literally means "oral instruction" (see Ó hÓgáin), embodies the orality which appears to be a common feature of the many attempted definitions. Seán Ó Súilleabháin explains it thus:

Folklore is a very comprehensive term to connote the complex of oral traditions of all peoples. It embraces not only their popular beliefs and customs, but also their traditional tales, legends, songs, proverbs, prayers, charms and riddles - in fact, any type of oral literature which has a more or less set form. It also includes local social history or seanchas,... (Irish Folk 8)

He further stresses that it represents the "continuation and survival of a very ancient way of thinking" (8). From a socio-historical perspective, folklore is a chain of very diverse links from the past into the present. It is a chain of transmission that connects generations, through a set of beliefs known to a particular community, or a shared store of narratives, or a common 
musical tradition for example. The variety that is intrinsic to folklore is visible also in its uses and reuses as indicated by Diarmuid Ó Giolláin:

'Folklore' is both subject matter and critical discourse, amateur enthusiasm and academic discipline, residual agrarian culture and the popular urban culture of the present; it is both conservative anti-modernist and radical counter-culture; the sphere of dilettantish provincial intellectuals and of committed nation-builders, transmitted by word of mouth in intimate settings and negotiated electronically in the public domain. (1)

Diarmuid Ó Giolláin echoes Máirtin Ó Cadhain's view about folklore "being born before our eyes here in Dublin, in London, in New York" and adds that "new versions of old things are always appearing" (Ó Giolláin 151). A good part of the research presented in this special issue rests on the concept of the "second life" of folklore, based on Lauri Honko's definition. The Finnish folklorist argued that the various forms that folklore takes are to be explained by its ability to spring back to life in different contexts. The "folklore process", beginning with the first life in which folklore is an "organic part" of a community, develops into its second life, which appears as a "recycling of material in an environment that differs from its original cultural context" after having been documented and preserved in archives (Honko 39; 48). Ó Giolláin corroborates this idea:

The 'second life' of folklore is everywhere around us. It is in vernacular references in architecture or interior design, in personal adornment, in marketing strategies for goods (a folkloric reference suggesting tradition, authenticity and naturalness), in staged performances of song and dance, in the display cases of museums, in the plots of cartoons, novels and films. It has become a part of the post-modern landscape. (174)

The articles of this issue exemplify the areas in which Irish folklore is being rejuvenated: musical compositions, short stories, performance, poetry, novels. But they also attest that Irish folklore is not dead: it lives on, still in its first life, in the fields of folk medicine and customs for instance. The ubiquitous and ambivalent process of folklore is thus both in its first and second lives, depending on a number of factors. To paraphrase Ó Giolláin, folklore truly is everywhere, either in its first life as a process experienced by and intrinsically part of a community, or as a reinvented cultural artwork. The folkloric process - or processes -, present in all areas of human life, in a variety of shapes and forms that cannot be clearly delimited, can thus be visualised as the rhizomatic web of Gilles Deleuze and Félix Guattari (13): a net of connections spreading in all directions, with no set trajectory, since it is a human process that changes as individuals understand, interpret, use and reuse it. The linear process that Honko described is indeed only a partial image of the protean lives of folklore. The variety of the research presented in this volume illustrates this rhizome of folklore in an Irish context, as do the origins and areas of expertise of the contributors and reviewers, which evidence how far-reaching the study of Irish folklore is.

Despite Honko asserting that "the phenomena in the second life of folklore have not been given their due value as research objects any more than as independent manifestations of tradition" (49), the study of the interactions between folklore and other forms of art has been developing over the past forty decades or so: Seán Ó Súilleabháin examined Synge's use of Irish folklore in 1972, Mary Helen Thuente published a monograph on Yeats and Irish folklore in 1980, and, for more contemporary authors, Bo Almqvist studied the mermaid motif in the poetry of Seamus Heaney and Nuala Ní Dhomhnaill, for instance. One of the 
most recent contributions to the field is a collection of essays edited by Anne Markey and Anne O'Connor in 2014, Folklore \& Modern Irish Writing. While the emphasis has been put on the relationship between folklore and literature in the previous scholarship on the subject understandably so, since storytelling is a major aspect of both - this special issue broadens the horizons by including other disciplines, such as music and performance studies. It also endeavours to be representative of Irish folk culture, since it includes examinations of both English- and Irish-language sources.

This issue brings together emerging scholars and renowned experts in the field of folklore and Irish studies, who are all researching developing areas of folklore studies. The new perspectives put forward in this collection thus concern both the authors and their subject matter. In the 2014 collection on folklore and Irish writing, Kelly Fitzgerald remarked the dual quality of contemporary folklore studies as such:

Folklore is no longer regarded as a finished product, an object in the field waiting to be collected and analysed. Instead, folklorists see the material they study as being intrinsic to all aspects of life. The process of engaging with the study of folklore is two-fold; it entails documenting the material and understanding its function. (30)

In accordance with what Kelly Fitzgerald has noted, the present essays focus not only on the aspects of folklore to be found nowadays, but also on the process at work, its function, origins and consequences.

While the regular issue of Estudios Irlandeses comes out each year on Saint Patrick's Day, this special issue is being published at another significant time of the year in Ireland, Oiche Shamhna, the night of Samhain, which was the Celtic festival marking the transition between summer and winter and has become our modern-day Halloween. It was believed that on this night the borders between this world and the Otherworld were blurred, allowing fairies and other supernatural beings into the human realm, as well as enabling mortals to cross over to a world of wonders, willingly or not (Danaher 200-207). In an apt parallel, this issue of the journal builds, or consolidates, bridges between the various disciplines in which folklore lives its first and second lives.

This volume was inspired by the work presented at the interdisciplinary conference entitled "New Crops, Old Fields - (Re)Imagining Irish Folklore 2" which was held in Belfast in June 2016. This symposium followed an earlier one which took place in 2013, the proceedings of which were edited by Eamon Byers and Conor Caldwell in 2015. We take this opportunity to thank the other members of the organising committees of both events: Eamon Byers, Conor Caldwell, Angela Goff, Pádraig Mac Congáil, Caoimhe Nic Lochlainn, Sheila Rooney and Rebecca Try.

While for technical reasons the articles are arranged alphabetically in this issue, the following paragraphs follow, as much as possible, a thematic order to introduce the wide range of materials discussed by the contributors. The range and interconnections among the articles highlight the interdisciplinarity of folklore studies in general and the importance of continuing the study of folklore in Ireland beyond the confines of literary analysis and traditional readings. Just as Irish folklore has been in the continuous process of re-creation and re-imagination in its many lives and circumstances, Irish folklore scholarship should also address and offer new perspectives on folklore in connection to other areas of artistic, social, and critical discourse in Ireland.

Among the topics discussed in this collection of essays, gender has particularly received a due amount of interest in three articles. Following the increasing trend of women studies in Irish folklore, Lillis Ó Laoire in "Tá cuid de na mná blasta/Some Women Are Sweet Talkers" focuses on representations of women in the field diaries of Seán Ó hEochaidh, 
one of the Folklore Commission's most prolific collectors from 1935 to 1971. Especially centring the paper to the study of six out of the ninety women mentioned in the eight volumes, Ó Laoire highlights the much-ignored role of "supporting women" - landladies, wives of storytellers, providers of hospitality, etc. - who played an important role in Ó hEochaidh's collection of folk tales. The article also sheds light on the lives of some working women in the thirties and forties in Donegal, where Ó hEochaidh did the majority of his work. Sometimes viewed as helpers, sometimes as hindrances in Ó hEochaidh's work, these women were far from being passive and "wielded considerable power and influence over the collector's circumstances".

Giovanna Tallone and Rebecca Graham have also dedicated their papers to the study of women and folklore, focusing on the fiction of Éilís Ní Dhuibhne, the eminent folklorist and storyteller. In "Stories Like the Light of Stars", Tallone investigates folklore and narrative strategies in the fiction of Ní Dhuibhne, discussing the link between folklore and storytelling. Drawing parallels between stories such as "The Search for the Lost Husband" and "The Mermaid Legend" and their folk versions, Tallone points to the "reinvention of folklore patterns" in Ní Dhuibhne's fiction, which establishes the link between tradition and modernity. The silenced and disturbing issues of abortion, child abuse, infanticide, discrimination, and the like, which haunt both traditional and modern Ireland, feature in Ní Dhuibhne's writing and emerge in new forms in her juxtaposition of the old and new. Tallone also highlights another important aspect of Ní Dhuibhne's writing: folklore is seen beyond its rural origins and instead sought after in the form of urban legends in modern-day Ireland. The writer's 1970s stories, such as "Fulfilment" appearing in The Shelter of Neighbours (2012), is an example of the permeability of folklore from rural to the urban and from tradition to modernity.

Drawing on Donna Haraway's cyborg feminism and Karen Barad's theory of diffraction, Graham's article, "The Foresight to Become a Mermaid': Folkloric Cyborg Women in Éilís Ní Dhuibhne's Short Stories" brings the focus to the issues of voice and orality and the female body in three short stories: "The Mermaid Legend," "Midwife to the Fairies," and "Holiday in the Land of Murdered Dreams". Ní Dhuibhne's repurposing of folklore, Graham argues, "is a radically feminist undertaking". The female protagonists featuring in the stories reveal "diverse, transgressive, sexual" femininities whose "symbolic connection to folklore" challenges female stereotypes and restrictive female identities in Ireland, allowing for alternative re-conceptions of identity and belonging in a feminist framework. According to Graham, "Ní Dhuibhne's shape-shifting, vocalizing female protagonists in her folkloric stories enact a kind of cyborg feminism which breaks down the binary logic of Western patriarchy" and offers possibilities "for multiple, radical, feminist futures".

"When 'She' Is Not Maud: An Esoteric Foundation and Subtext for Irish Folklore in the Works of W.B. Yeats" by Nick Serra offers a fresh perspective on W.B. Yeats's use of Irish folklore and his engagement with the occult. Serra reviews the esoteric aspects of W.B. Yeats's use of folklore, especially in connection to his most enigmatic work, A Vision, and deviates from the mainstream academic opinion that downplays or aestheticizes Yeats's belief in the supernatural. Serra examines the reason/s behind Yeats's use of Irish fairylore by drawing on the poet's experimentation with the occult, especially during his thirty years of involvement in MacGregor Mathers' Hermetic Order of the Golden Dawn. According to Serra, the poet intended to justify and validate "his pre-existing emotional belief in the folklore of the country people". The connections between folklore and the occult examined in the essay provide a new perspective on "Yeats's ideas about Unity of Being, and hypothesizes a possible esoteric path to 'escape' from his system of phases so as to resolve the body-soul dilemma evident in his poetry". 
Moving from Yeats to another major influence in the history of Irish literature, Flann O'Brien, in "Between Folk and Lore" Vito Carrassi draws on Lauri Honko's "first" and "second life" of Irish folklore and points to the links that exist among performance, textualisation, understanding and at times misunderstanding of Irish folklore. Carrassi points to how Flann O'Brien's An Béal Bocht reveals "bitter truths" about Irish folklore being misunderstood and sometimes betrayed by the Irish themselves, mostly by those trying to preserve "the so-called ancient and declining heritage of Irish folklore". As Carrassi states, the likes of Flann O'Brien reminded the literary scholar and collector to view folklore in its entire life, and to take into consideration "the dynamism of a living tradition which continued to be performed in a variety of contexts". Carrassi points out to the importance of viewing folklore as a living tradition among people and highlights the inseparability of the "lore" from the "folk" creating it.

Also referring to Lauri Honko's definition of the "first" and "second" life of folklore, Rosari Kingston in "Folk Medicine and Its Second Life" questions whether Irish folk medicine is living its second life or should rather be seen as "modern attestations of a living vernacular tradition". To answer the question, she presents an account of thirteen interviews with healers from all parts of Ireland in the course of four years from 2012 to 2016. The variety of healing practices include, charms, blessings, plant formulae, bone-setting, rituals and cupping. Referring to elements of folk medicine, including dislike of publicity, lineage, oral tradition, and sense of identity, Kingston places the study of Irish folk medicine within the larger context of Irish folk culture and its relation to the Irish belief in the supernatural. To the testimony of all thirteen healers, folk medicine is still alive and quite vibrant throughout Ireland and should be perceived as still living its first life. Kingston comments that modern Irish folk healers operate within a fundamentally traditional framework and highlights the vibrant nature of folk healing in Ireland and its continued relevance within the community.

Performance is another important aspect of Irish folklore in its first and second lives, linking tradition to modernity. Daithí Kearney's essay, "Reliving Island Life", on the development of Siamsa Tíre, The National Folk Theatre of Ireland, from the perspective of ethnomusicology highlights this particular aspect of Irish folklore. Kearney focuses particularly on the production of Oiléan, a commemorative piece of "folk theatre" that loosely narrates the stories and traditions of Blasket Islanders through music, song, and dance rather than "spoken dialogue". The last inhabitants of the island left in November 1953, and the production which nowadays draws a large group of tourists to the show "provides an opportunity for a second life to the folklore and customs of the island". As Kearney stresses, Oiléan is a link between tradition and modernity, between the rural and urban, for the audience at home and tourists alike.

Angela Goff's "The Ulster Cycle: Cultural Significance for Irish Composers" is a musicological approach to the study of music and literature in Ireland. Providing a literary background to the importance of Irish Saga Literature (600-1200 C.E) and focusing on the ancient tales of the Ulster Cycle, Goff discusses the cultural significance of the sagas for Irish composers from the early nineteenth century to modern times. The article discusses a variety of musical composition by fifteen musicians, including Aloys Fleischmann, Patrick Cassidy, James Wilson, Eibhlís Farrell, and Fergus Johnston, which retell the ancient tales of the mythological hero Cú Chulainn, the tragic heroine Déirdre, the war goddesses Morrígan and Macha, Fand, wife of the sea god Manannán mac Lir, and the story of the Táin. Each musician tackles the question of Irish identity and its relation to older tales in a distinct manner and in doing so, they have gradually found "more progressive ways to employ the ethnic" repertoire in their music. Sweeney's "Hiberno-minimalism", Farrell's "engagement with early Baroque music", and Johnston's "writing for an electronic medium" are examples 
where Irish composers have created an individual version of Irish identity within a pluralistic Irish culture.

Frédéric Armao in "Cathair Crobh Dearg: From Ancient Beliefs to the Rounds 2017" provides an interdisciplinary study of the mystical and enigmatic site of Cathair Crobh Dearg in Co. Kerry and the twin mountains of Dá Chích Anann (the Paps of Anu), surrounding the enclosure. Relying on field research and building on existing archaeological evidence, as well as documents from the Irish National Folklore Collection, and mythological, folkloric, and ethnographic studies, the paper promises a "first step towards a fuller understanding of the site, its original significance and its evolution through centuries". The place is especially visited on pattern days, around the festival of Bealtaine in May, which marks the transition between spring and summer. The mythological significance of the site and its possible connection to the present day religious and traditional significance is brought to attention through an account of the author's recent visit on 1 May 2017 to the site. Armao has also observed the two cairns built on top of the twin mountains and investigated their possible links with Irish mythology, namely with the goddess D/Anu or with the Tuatha Dé Danann. The combination of archaeology with Irish literary and folklore sources, along with the researcher's personal observation of the site in our times is another reminder of the interdisciplinarity of any study that deals with Irish folklore.

In this light, the last of the essays deals with one of the newest fields of critical discourse, i.e. the intersection of human rights, poetry and folklore. In "Of Mermaids and Changelings: Human Rights, Folklore and Irish Language Poetry”, Rióna Ní Fhrighil crosses this intersection through a fresh analysis of Louis de Paor and Nuala Ní Dhomhnaill's poetry in Irish. By focusing on the folk motifs of the mermaid and the changeling in particular, the essay brings to attention "how oral traditions influence the form and content of Irish-language human rights poetry and to what end". Both de Paor and Ní Dhomhnaill go beyond imagining Irish folklore and render a re-imagination of what may be considered as "international folklore motifs, inflected by local variations, which sometimes precede debates in human rights about the universality of the human rights discourse". Ní Fhrighil tackles the ethical imperative of poetic works that utilise images of international atrocities and the violence of folklore as metaphors of personal expression, and argues for caution in both the construction and reading of these works. The human rights discourse, as Ní Fhrighil reminds us, "is a valuable critical lens in the discussion of twentieth and twenty-first century Irish-language poetry".

We would like to conclude by expressing how very grateful we are to the contributors for sharing their in-depth research and to the reviewers who helped make this issue a valuable contribution to Irish folklore studies.

\section{Works Cited}

Almqvist, Bo. "Of Mermaids and Marriages: Seamus Heaney's 'Maighdean Mara' and Nuala Ní Dhomhnaill's 'An Mhaighdean Mhara' in the Light of Folk Tradition”. Béaloideas 58 (1990): 1-74.

Byers, Eamon and Conor Caldwell, eds. 2015. New Crops, Old Fields: Reimagining Irish Folklore. Bern: Peter Lang, 2015.

Danaher, Kevin. The Year in Ireland. Cork: Mercier Press, 1972.

Deleuze, Gilles and Félix Guattari. Capitalisme et Schizophrénie. Mille Plateaux. Paris: Éditions de Minuit, 1980. 
Fitzgerald, Kelly. "From Product to Process: The Emergence of the National Folklore Collection". Folklore and Modern Irish Writing. Eds. Anne Markey and Anne O'Connor. Sallins, Co. Kildare: Irish Academic Press, 2014. 21-32.

Honko, Lauri. Theoretical Milestones, Selected Writings of Lauri Honko. Eds. Pekka Hakamies and Anneli Honko. Helsinki: Folklore Fellows' Communications 304, 2013.

Markey, Anne and Anne O'Connor, eds. Folklore \& Modern Irish Writing. Sallins, Co. Kildare: Irish Academic Press, 2014.

Ó Giolláin, Diarmuid. Locating Irish Folklore: Tradition, Modernity, Identity. Cork: Cork University Press, 2000.

Ó hÓgáin, Daithí. "Béaloideas - Notes on the History of a Word”. Béaloideas 70 (2002): 8398.

Ó Súilleabháin, Seán. Irish Folk Custom and Belief. Dublin: The Three Candles, 1967. . "Synge's Use of Irish Folklore". J. M. Synge: Centenary Papers 1971. Ed. Maurice Hamon. Dublin: Dolmen Press, 1972. 18-34.

Thuente, Mary Helen. W. B. Yeats and Irish Folklore. Dublin: Gill and Macmillan, 1980.

Warner, Marina. Managing Monsters: Six Myths of Our Time, The Reith Lectures 1994. London: Vintage, 1994.

\section{Archival Sources}

National Folklore Collection, Schools' Collection (NFCS) 72: 249; "Lá Fhéile Samhna", collector: Sorcha Ní Fháthairtaig, Teeranea, Co. Galway. Teacher: An tSr. M. Benín.

Audrey Robitaillié is interested in contemporary literature and Irish folklore, as well as the various ways in which they interact. Her PhD thesis (at Queen's University Belfast and the University of Caen) investigated the folklore surrounding changelings and fairy abductions and its reuse in literature. She is the lead organiser of the interdisciplinary research forum, "New Crops, Old Fields - (Re)Imagining Irish Folklore". Her article on changeling pipers is forthcoming in the journal Folklore (December 2017). She is also particularly interested in notions of home and belonging in contemporary literature, and has been researching the works of Colum McCann and Hugo Hamilton.

arobitaillie01@qub.ac.uk

Marjan Shokouhi holds a PhD in English from the University of Sunderland, UK. Her doctoral thesis focused on an ecocritical study of modern Irish poetry. She is a committee member of the "New Crops, Old Fields" research forum, which focuses on the study of Irish folklore and its reuses. She has published a number of essays and critical reviews on W.B. Yeats, Louis MacNeice, Patrick Kavanagh, Samuel Beckett, Anna Liddiard, etc. Her fields of interest include environmental studies, Irish literature, modern poetry, and creative writing.

marjan.shok@gmail.com 